\title{
Germplasm Resources in Vietnam: Major Horticultural and Industrial Crops
}

\author{
Hoan T. Le and James F. Hancock \\ Department of Horticulture, Michigan State University, East Lansing, MI 48824-1325 \\ Ton-That Trinh \\ 41 Del Cambrea, Irvine, CA 92714 \\ Pham-hoang Ho \\ 7005 Ste. Dominique, Apt. 3. Montreal, PQ, H2S 3B6, Canada
}

Situated on the east bank of the Pacific Ocean, Vietnam has a diverse ecogeographic range and an unusually high diversity of species. There are two major eco-zones, one in the north with distinct seasonal temperature changes, including a cold winter, and one in the south with typical tropical climate. The dividing line between these zones is at the Hai Van Pass, $16.5^{\circ} \mathrm{N}$ (Vu-tuyen, 1996). The country is divided into seven major agro-ecozones from north to south: 1) the northern hilly and mountainous region; 2) the Red River Delta; 3 ) the northern part of the central coast line; 4) the southern part of the central coast line; 5) the central highland; 6) the area northeast of the Mekong Delta; and 7) the Mekong River Delta (Fig. 1) (Vien Quy Hoach va Thiet Ke Nong Nghiep, 1997; Vu-tuyen, 1996). The large and heterogenous zone 1 is further divided into: 1) northern mountainous; and 2) northern midland zones (Nguyen-huu and Ngothe, 1996).

About $40 \%$ of the country's plant and animal species are endemic (Government of the Socialist Republic of Vietnam and Global Environmental Facility, 1994). The highest levels of endemism are concentrated in four regions: 1) the Hoang Lien Son Mountains in the north; 2) the humid forest of the northern part of central Vietnam; 3) the Ngoc Linh mountains in the center of the country; and 4) the Lam Vien highlands in the south (Fig. 1) (Tran-dinh, 1996a). The World Conservation Monitoring Center (WCMC) has rated Vietnam as the $16^{\text {th }}$ most biologically diverse country in the world (Socialist Republic of Vietnam, 1992).

There are more than 12,000 native plant species in Vietnam, with $\approx 10,500$ described to date (Pham-hoang, 1991, 1992, 1993). At least 40 crop species have part of their distribution range in Vietnam (Government of the Socialist Republic of Vietnam and the Global Environmental Facility, 1994). The numbers of edible fruit and vegetable species approach 1500 , and nearly 2100 species are used as medicines in Vietnam.

\footnotetext{
Received for publication 9 June 1997. Accepted for publication 15 June 1998. Thanks to Marlene Cameron for polishing the artwork developed by Hoan T. Le. The cost of publishing this paper was defrayed in part by the payment of page charges. Under postal regulations, this paper therefore must be hereby marked advertisement solely to indicate this fact.
}

This biodiversity has been shaped not only by the geographical and environmental variability of Vietnam, but also by the equally diverse cultures of its more than 50 ethnic groups. The Kinh ethnic group, which constitutes $87 \%$ of the population, still practices paddy rice-based cultivation (Do-dinh, 1994). However, 50 other ethnic groups of $\approx 9$ million people rely on a much more complex array of foods in the mountainous regions of the country. These peoples practice primarily shifting cultivation, except in areas adjacent to the Red

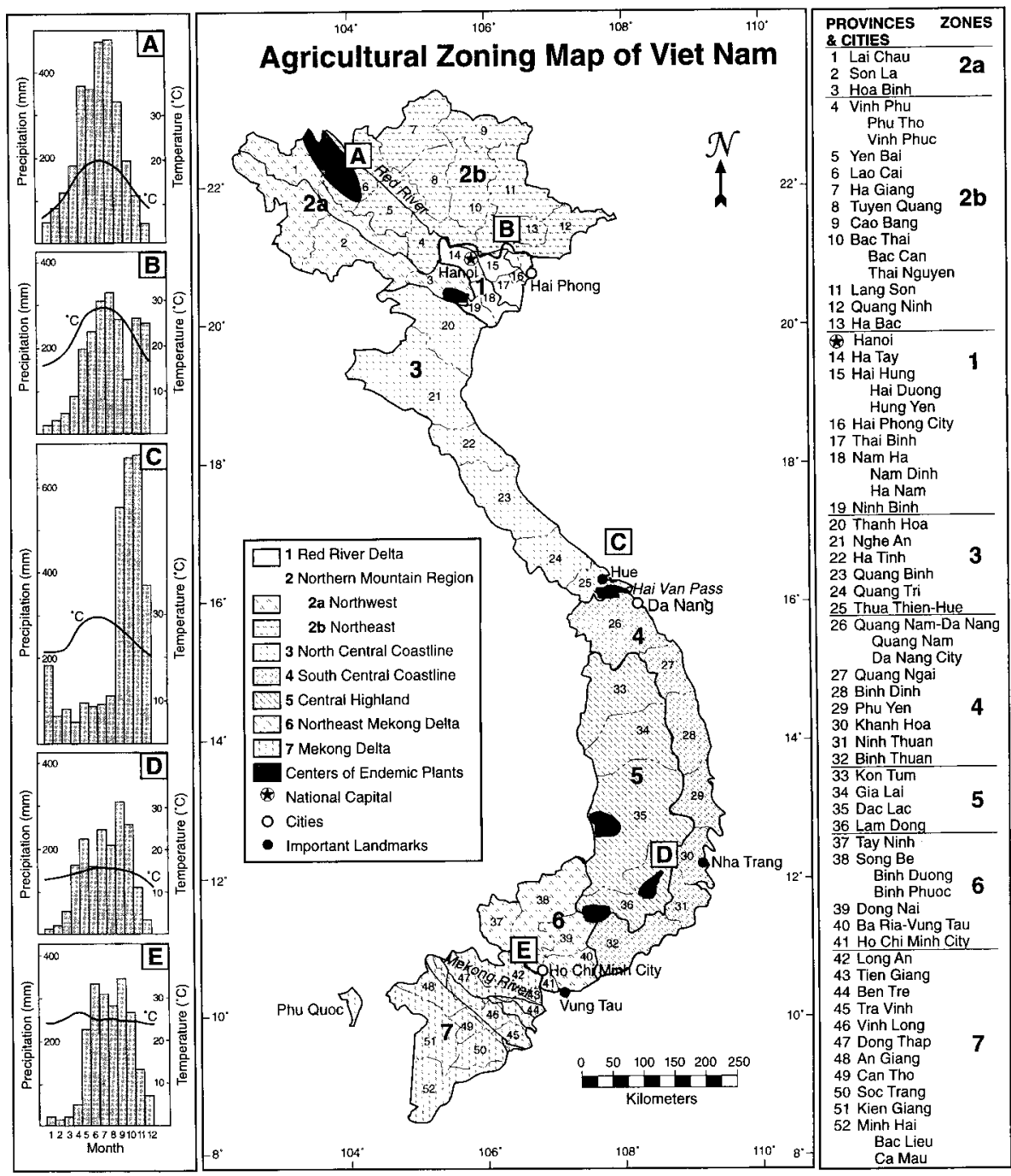

Fig. 1. Agricultural zoning map of Vietnam based on a hand-drawn map from the Dept. of Plant Protection, Ministry of Agriculture and Food Industry, Hanoi, 1994. The provinces and cities were based on 1) an administrative map of Viet nam-Lao-Cam pu chia published in 1993 in Dalat, Vietnam, and 2) a map drawn by the World Bank (Denning and Vo-tong Xuan, 1995). The histograms for precipitations and temperatures were obtained from a geographic map (Socialist Republic of Vietnam, 1988). The centers for endemic plants were derived from maps prepared by the World Conservation Monitoring Centre (Socialist Republic of Vietnam, 1992), the Government of the Socialist Republic of Vietnam, and the Global Environmental Facility (1994). 
River Delta, where the Muong, Tay, Nung, and Thai practice both shifting and paddy ricebased agriculture (Do-dinh, 1994).

The goals of this paper are to describe some of the most important horticultural and industrial crop species that are found in Vietnam and to review how that germplasm is being conserved. Where appropriate, we also list close relatives and note how they are utilized. The Vietnamese common name for the crop is listed in parentheses, following its English name. In our citations of Vietnamese authors, we have separated the last and middle names of each author with a hyphen. We also spell out the authors first name in the literature cited, as is the custom in Vietnam. This helps differentiate one author from another, as there are relatively few Vietnamese surnames.

This paper was stimulated by two visits made by one of us (H.T.L.) to universities and agricultural research institutions in Vietnam under an internship granted by the International Development Research Centre (IDRC) of Canada. The trips were taken in 1994 and 1995 for 2 weeks and 4 months, respectively. Both local scientists and farmers were consulted, including the occupants of two hamlets in the watershed of the Da river in Hoa Binh province of Northern Vietnam (Ban Tat and Ban Yen of the Tay, and the Dao peoples, respectively).

\section{ROOT AND TUBER CROPS}

\section{Taro ("Mon” or "So", "Nua" and "Ray")}

Taro of the Araceae family plays a particularly important role in marginal areas of northern and central Vietnam, where poor soil, typhoons and floods result in frequent losses of the rice harvest. Pham-hoang (1993) described 95 native species of taro in Vietnam that are found in a diverse range of shaded environments, from rocky mountain slopes to wet valleys and flatlands. The most important food and feed genera are: Colocasia ("Mon" and "So"), Alocasia ("Ray"), Amorphophallus ("Nua"), Cyrtosperma ("Ray"). Aroids are also used for medicine in Vietnam, including numerous species of Lasia ("Ray Gai"), Typhonium ("Bac Ha"), and Homalomena ("Thien Nien Kien") (Pham-hoang, 1993).

The most important food species, Colocasia esculenta L. Schott. ("Khoai Mon" or "Khoai So" or "Mon Nuoc"), is found wild in northern Vietnam and cultivated countrywide (Phamhoang, 1993). While it is used primarily for staples, the landraces Mon Trang, Mon Sen, Mon Do Loi, and, particularly, Mon Tim are used to prepare a popular dessert enjoyed by people in the former imperial capital of Hue. A giant wild relative species, $C$. gigantea (B1.) Hook. F. ("Mon to"), is found in Dinh Quan, South Vietnam.

At least 11 Alocasia and seven Amorphophallus species are utilized in Vietnam (Pham-hoang, 1993). Alocasia odora C. Koch. ("Bac Ha" or "Doc Mung") is popularly cultivated countrywide for its leaf petioles, which are consumed as vegetables. Four species, Alocasia macrorrhiza (L.) G. Don, A. indica (Lour.) Kunth.,Amorphophallus konjac K. Koch., and A. peoniifolius (Denst.) Nicols. var. campanulatus (Roxb.), are cultivated in northern and central Vietnam. Petioles, stems, and tubers are normally used as animal feed, but are also fit for human consumption if cooked for a long time with lime to remove bitterness and other irritants that cause itchiness. Another edible, wild species of Amorphophallus is A. interuptus Engler and Gehrm. A giant Amorphophallus of an undescribed species is found on the island of Phu Quoc, in South Vietnam, and A. tonkinesis occurs in Ha Nam Ninh, Hanoi, and Lai Chau in northern Vietnam. Cyrtosperma merkusii (Hassk.) Shott., found wild in swampy areas across the country, has roots that can weigh 70 kg (Pham-hoang, 1993).

The first systematic collection of aroids was made in 1992 by the former Potato and Vegetable Research Center, now the Root Crop Research Center (RCRC) of the Vietnam Agricultural Science Institute (VASI), with technical support from the Centro Internacional de la Papa (CIP) (Truong-van and Nguyenngoc, 1996). This taro germplasm was evaluated at selected locations with farmers' collaboration and superior lines were released for wider cultivation. Another 55 taro accessions were collected by VASI in 1994 in Son La, Lai Chau, and Yen Bai provinces, with assistance from the Japan National Agricultural Research Center, the National Institute of Agro-biological Resources (NIAR), and the Osaka Agrobiological Resources Center (Tran-dinh, 1996b). The RCRI currently has 402 taro accessions belonging to 15 genera and 39 species of the Araceae family. Their relative proportions are: $72 \%$ Colocasia; $20 \%$ Xanthosoma (an introduced species, native to tropical America); 3.8\% each of Alocasia and Cyrtosperma; $1.8 \%$ of Amorphophallus; and $<1 \%$ Typhonium and Schizocasia (Truongvan and Nguyen-ngoc, 1996).

\section{Yam (“Khoai Tu” and "Khoai Mo")}

As with taro, yams play an important role as famine insurance in Vietnam. Pham-hoang (1993) described a total of 39 species of Dioscorea in Vietnam, including the important worldwide food crops $D$. alata L., $D$. esculenta (Lour.) Burk., and D. bulbifera L. (Hahn, 1995). Several Vietnamese yam species are used by indigenous people for purposes other than food, including medicine $(D$. persimilis Prain and Burk.), botanical pesticides (D. hisipida), and dyes (D. cirrhosa Prain and Burk.). Three Vietnamese species of Dioscorea were listed as rare by the WCMC, including $D$. dissimulans, $D$. petelotii, and $D$. poilanei, all described by Prain and Burkill (Socialist Republic of Vietnam, 1992). Seventy-two yam accessions representing 13 species have been collected by the RCRI, and are being maintained in the field, in pots and in vitro. Dioscorea alata represents $60 \%$ of the accessions collected, while D. esculenta represents $24 \%$.
TROPICAL FRUITS

\section{Ensete and Musa bananas (“Chuoi”)}

Vietnam is in the center of the distribution range of both Ensete and Musa (Simmonds, 1995). Vietnamese germplasm played an important role in the world banana industry, as resistance to Panama wilt disease was found in the Saigon Botanical Garden in 1925 and was used to develop 'Valery', a variety that helped reestablish the banana industry in Central America (Plucknette et al., 1987).

Thirteen species of Musa are found in Vietnam, including the two important donors of the A and B genomes, M. acuminata Coll. and M. balbisiana Coll. (Pham-hoang, 1993). Other notable cultivated species include the so-called hundred-bunched banana, $M$. chiliocarpa Back., which has an extremely long inflorescence that reaches the ground; $M$. textilis Nee., cultivated for its fiber; the short banana M. nana Lour. ("Chuoi Gia Lun"), which is only $1-2 \mathrm{~m}$ tall; and the large-trunked M. bakeri Hook. f., which has triangular fruits $4-5 \mathrm{~cm}$ in length in a drooping inflorescence (Pham-hoang, 1993).

The most important cultivated species is $M$. paradisica, with at least 45 landraces being grown in southern Vietnam (Pham-ngoc and Pham-van, 1995). One of the most popular landraces is "Chuoi Ngu" from the provinces of Dong Nai and Gia Dinh. Chuoi Ngu, as its Vietnamese name suggests, was once reserved for the sovereigns. It has small fruits, a thin peel, and sweet flesh that the Vietnamese consider to be tastier than the M. cavendish groups grown in South America. Other popular South Vietnam landraces of this species are "Chuoi Gia," "Chuoi Cao," "Chuoi CaoLua," and "Chuoi Tieu Hoa" (Ton-that, 1973). In northern Vietnam, the landraces "Nam Dinh" and the "Hung Yen" are highly esteemed for their aroma and taste (Le-dinh, 1996).

Numerous species of bananas are cultivated as ornamentals across Vietnam. These are: 1) M. coccinea Andr. ("Chuoi Sen") (M. uranosscopos Lour., non Rump.) with red petals, yellow flowers, and little finger-sized fruits; 2) M. rosacea Jacq. ("Chuoi Kieng" and "Chuoi Huong"), which has light green, violet, or yellow petals and green stigmata; 3) $M$. ornata Roxb. ("Chuoi Kieng Do"), which has flowers with bright red or orange petals; and 4) M. sanguinea Hook. f. ("Chuoi Kieng Do"), which has dark red petals and yellow-seeded fruits with red stripes.

Several collections of Vietnamese banana germplasm have been made in the last decade. Over 100 representatives of $\mathrm{ABB}, \mathrm{BBB}$ and AAB genomes, identified only as South East Asian cooking bananas, were collected in 1994 by the Phu Ho Fruit Crop Research Center (PHFCRC) with assistance from International Plant Genetic Research Institute (IPGRI) and International Network for the Improvement of Banana and Plaintain (INIBAP) (IPGRI, 1994). This collection may contain the 20 individuals of five Eumusa species mentioned by Le-dinh (1996) as growing wild in Yen Bai, Son La, and Lao Ca. Another 19 accessions belonging 
to the wild species $M$. balbisiana, M. itinerans, $M$. ornata, and M. barneesis were collected in 1994-95 by VASI (Tran-dinh, 1996b).

\section{Citrus-Orange ("Cam"), Lime and Lemon ("Chanh"), Mandarin ("Quit"), and Pummelo ("Buoi" and "Bong")}

Vietnam is in the center of diversity of citrus. While most recent taxonomic treatments of citrus consider the primary species of citrus to be $C$. medica L. (citron), C. reticulata B1. (mandarin), and C. maxima [Burm.] Merr. (pummelo) (Scora, 1988), most Vietnamese literature on citrus is based on either Swingle and Reese's (1967) more complex classification system (Do-dinh, 1996), horticultural groupings (Ton-that, 1995), or other taxonomic characteristics (Pham-hoang, 1992). We will generally follow the designations of Phamhoang (1992), as his taxonomy is the most comprehensive available for the region.

Pham-hoang (1992) described a total of seven taxa in Vietnamese forests. He gave the native range of five: 1) $C$. annamensis Tan. ("Cam Hoi") in Phu Hu and Phu Khanh; 2) C. depressa Hay. in Quang Tri; 3) C. macroptera Montr. var. annamensis Tan., which is widespread in Nha Trang; 4) C. aurantium L. (the sour orange) on Nui Cam in Chau Doc; and 5) C. aurantium sub. ichangensis Guill. var. latipes Guill., a hybrid of $C$. grandis and $C$. reticulata, in Sapa. The two forest species with unspecified locations are $C$. amblycarpa (Hassk.) Ochs. ("Quit Ta") and C. hystrix DC. Citrus depressa and $C$. amblycarpa are notable in that they have few to no spines. Citrus macroptera has unusually large fruits $(10 \mathrm{~cm}$ in diameter), and C. amblycarpa has bright yellow, sour fruit. Citrus hystrix is thought to be tolerant to flooding.

There are a number of ancient cultivated taxa of citrus grown in Vietnam. Some of these were introduced long ago from nearby regions, or were directly domesticated from Vietnamese relatives. These are: 1$)$ the lime, $C$. aurantifolia (Chritm.) Sw. ("Chanh Ta") of Malaysian origin, which is popular not only for its juice but also for its spicy leaves; 2) a clementine, C. nobilis var. chrysocarpa Lamk.; and 3) the mandarins, $C$. nobilis Lour. var. nobilis, C. nobilis var. microcarpa Hassk., and C. deliciosa Tan. Seven landraces of mandarin are referred to as "Cam" in South Vietnam, with "Cam Sanh" and "Cam Mat" being the most popular. A seedless "Cam Mat" was discovered in Vinh Long (Pham-ngoc and Pham-van, 1995). Six land races of mandarin are called "Quit," with the three most popular being "Quit Tieu Hong," "Quit Tieu Nghe," and "Quit Duong" (Pham-ngoc and Phamvan, 1995). The species relationships of all these landraces are blurred; however, they fall under the broad umbrella of $C$. reticulata $\mathrm{Bl}$., and originated in the Mekong Delta (Ton-that, 1995).

There are several other important cultivated taxa of citrus with ancient origins. Pummelo, C. grandis (L.) Osb. var. grandis ("Buoi"), includes the landraces "Nam Roi" in Vinh Long, "Duong Da Lang," "Duong Hong" and "Bien Hoa" in Bien Hoa, "Thanh Tra" in central Vietnam (Pham-hoang, 1992; Phamngoc and Pham-van, 1995), "Doan Hung" in the Chi Dam district, and "Phuc Trach in the Ha Tinh province (Tran-dinh, 1996b). Despite its high quality, few plants of "Bien Hoa" are still being cultivated because of its low yields. The citrons include $C$. medica L. sub. bajoura Bon. with landrace "Thanh Yen" and C. medica var. sarcodactylis (Sieb) Sw. ("Phat Thu") (Pham-hoang, 1992). A sweet orange, $C$. sinensis (L.) Osb. ("Cam"), a South China native and a hybrid of $C$. grandis and $C$. reticulata (Sauer, 1993), is also popularly cultivated. A highly esteemed landrace named "Xa Doai" is grown in Nghe An (Ton-that, 1995).

Other cultivated citrus taxa of recent introduction are grapefruit ("Buoi Dang") $[C$. grandis var. racemosa (Roem.) B. C. Stone, also called $C$. paradisi Macf.], and lemon ("Chang Tay") [C. limon (L) Burm.f., or $C$. medica subsp. limon L.]. The former is a hybrid between $C$. grandis and $C$. sinensis (Sauer, 1993) and the latter a hybrid between C. medica and C. aurantifolia (Sauer, 1993). Both grapefruits and lemons are cultivated in Dalat. They are not, however, widely consumed (Pham-hoang, 1992). Citrus limonia Osb. ("Chanh Hanoi" or "Citron de Canton") is cultivated in Quang Tri and Lam Dong in Central Vietnam (Pham-hoang, 1992). It may be a hybrid of $C$. aurantifolia $\times C$. reticulata (Sauer, 1993) or C. limon $\times$ C. reticulata (Pham-hoang, 1992). Another species related to the Chanh group, C. limonellus Hassk., was briefly described by Pham-hoang (1992) as a small tree without spines, but no other information was given.

With support from the National Plant Genetic Network, 185 cultivars of citrus have been collected from 11 provinces in northern Vietnam. Swingle and Reese's classification (1967) was used and the cultivars were classified into nine species and two forms, including C. sinensis, C. limon, C. aurantifolia, $C$. aurantium, $C$. jambishi, $C$. reticulata, $C$. grandis, $C$. paradisi, $C$. medica, $C$. sinensis $\mathrm{x}$ $C$. reticulata, and Citrus sp. The $C$. grandis and $C$. reticulata were represented by the highest number of cultivars collected (73 and 46, respectively). The $C$. medica collections include three forms with very different plant shapes: C. medica ("Bong"), C. medica var. ethrog ("Thanh Yen"), and C. medica var. saccodactylis ("Phat Thu" or "Buddha's hand") (Do-dinh, 1996). Landraces of $C$. reticulata fell into nine morphological groups that clustered around their place of origin and exhibited a wide range of fruit ripening dates. The early ones, "Sour" and "Giay" mandarins, are ready for harvest in September or October; the midseason ones, "Tich Giang," "Dong Khe," "Dan Ha," and "Bac Giang" ripen in November and December; and the late ones, "Chun," "Chum," "Bac Quang," "Duong Yen Bai," and "Cam Sanh" mandarins, ripen in December and January.

Citrus collections are also being maintained at the PHFCRC. According to Le-dinh (1996), 57 accessions of citrus are being main- tained there. In another report, 48 cultivars, with 170 surviving trees, are listed; these may be the remnants of an original collection of 185 samples (Do-dinh, 1996).

\section{Mango ("Xoai”)}

The native distribution of several Mangifera species includes Vietnam. The two most common are: 1) M. foetida Lour. ("Xoai Hoi" or "Muom"), which is located in both northern and central Vietnam (Do-tat, 1986; Phamhoang, 1993) and has sour fruits with thin pulp; and 2) M. caloneura Kurz. ("Queo" and "Xoai Lua"), which is distributed countrywide in wetlands and has flaming red fruits, as its Vietnamese name denotes. Three mango species are found in central and South Vietnam. Mangifera dongnaiensis Pierre, "Dong Nai" or forest mango ("Xoai Dong Nai" and "Xoai Nui"), which is found in wet, submontagne, and evergreen forests along the river Dong Nai south of the Di Linh highlands. The forest mango is distinguished by its long inflorescence of 10-20 cm length, with fruits tilting at its ends. Mangifera flava Evr. ("Xoai Vang") is found in central Vietnam in the provinces of Quang Nam and Phan Rang. It has small (4 cm long), round, and yellowfleshed fruits, which bulge on their sides. Mangifera longipes Griff. or M. laurina Bl. (Kosterman and Bompard, 1993) ("Xoai Cong Dai") is a very large tree ( $40 \mathrm{~m}$ tall) with red wood and sparse inflorescences. Two mango species are endemic to Vietnam. Mangifera cochinchinensis Engl. ("Xoai Nut") is distributed in the provinces of Bien Hoa, Binh Duong, and Thu Dau Mot, near Ho Chi Minh City, and has small fruits $\approx 3 \mathrm{~cm}$ long. Mangifera minutifolia Evr., Forest Mango ("Xoai Rung") or Small Leaf Mango ("Xoai La Nho"), is a medium-sized tree $25 \mathrm{~m}$ tall, and is distributed only above $600 \mathrm{~m}$ in Phu Khanh, near Nha Trang. Mangifera cochinchinesis and M. flava are on the endangered list of the WCMC, and M. minutifolia is rare and may be at risk (Socialist Republic of Vietnam, 1992).

There are also two species of Bouea that should probably be considered as native mangoes. Bouea oppositifolia (Roxb.) Adelb. or M. oppositifolia Roxb. ("Thanh Tra") is found in evergreen forests in Chau Doc province and Phu Quoc island. It has egg-sized fruits with a sour taste. Bouea poilanei Evr. ("Xoai Mu" and "Xoai Muc") is found in Trang Bom and has red fruits. Kostermans and Bompard (1993) recently excluded these two species from their latest mango taxonomy; however, they acknowledged that several species from Indochina remain poorly described.

Two mango species are cultivated in Vietnam: 1) M. odorata Griff., fragrant mango ("Xoai Thom"), which has fibrous seed and sweet, yellow-fleshed fruits; and 2) $M$. indica L., the most important species worldwide, which was probably introduced by Buddhist monks from India around 4 BC (de Laroussilhe, 1980). Eleven landraces of $M$. indica have been described in South Vietnam. The most important ones are "Xoai Cat Hoa Loc" in Cai Be and Tien Giang; "Xoai Cat Chu" and "Xoai 
Thom" in Dong Thap; and "Tien Giang" and "Xoai Buoi" (also called "Xoai Ba Mua Mua"). The last-named is very popular among mango farmers (Pham-ngoc and Pham-van, 1995). Other well-known landraces of $M$. indica found in South Vietnam are "Xoai Tuong," "Xoai Cat," "Xoai Thanh Ca," and "Xoai Com". In northern Vietnam, "Xoai Yen Chau" in Son La is the most esteemed (Tran-dinh, 1996b).

\section{INDUSTRIAL CROPS}

\section{Bamboo ("Tre" and "Truc")}

Bamboo has played an important role in Vietnamese culture. Most Vietnamese remember the green bamboo trees of their home villages, regardless of where they have settled. Dominant bamboo forests occupy an area of 580,120 ha or $11.4 \%$ of the total forest cover in Vietnam, and mixed forest bamboo occupies another 316,271 ha (Vien Kinh Te Sinh Thai, 1994). Bamboos are revered in classical literature, music and folklore and play a critical role in day-to-day Vietnamese life. They are used for their edible shoots, and women earn extra income by collecting bamboo shoots from the forest and selling the dried products. Bamboo is used in building construction, chopsticks, hats, musical instruments, and home furniture, such as chairs and beds. Bamboo forests can produce as much pulp for the paper industry as woody forests, and in much less time; the rotation cycle for bamboo forests is only 3 years (Vien Kinh Te Sinh Thai, 1994).

Pham-hoang (1993) described 18 genera and 97 species of the sub-family Bambuseae of the Poaceae in Vietnam. There are seven genera that have major economic valueArundinaria ("Sat"), Bambusa ("Tre"), Phyllostachys ("Truc"), Dendrocalamus ("Luong"), Sinarundinaria ("Sat"), Lingnania ("Dung"), and Oxytenanthera ("Le").

Bambusa is the most widespread bamboo genus in Vietnam, occupying $\approx 80 \%$ of the bamboo cover from the lowlands to the highlands (Vien Kinh Te Sinh Thai, 1994). Phamhoang (1993) lists a total of 27 Bambusa species, the most important of which are $B$. vulgaris Schreder ex.Wendl. ("Tre Nha”), $B$. stenostachya Haeckel ("Tre Gai”), B. procera Chev. and Cam. ("Tre Lo O"), B. arundinacea ("Tre Loc Ngoc"), B. multiplex (Lour.) Raeusch. ("Tre Hoa"), and B. ventricosa McClure ("Truc Bung Phat," "Truc Dui Ga”). These species are cultivated for the paper and pulp industries and account for $60 \%$ to $70 \%$ of the raw materials used in the northern provinces of Tuyen Quang, Yen Bai, Vinh Phu, Bac Thai, and Thanh Hoa and the southern province of Song Be (Vien Kinh Te Sinh Thai, 1994).

Arundinaria ("Sat") species occupy $\approx 15 \%$ of the total bamboo forest cover and have a particularly high economic value in the midlands. This genus is used in the pulp and paper industries, in building construction, and for its edible shoots. Some of the most important Arundinaria species are A. sat Bal. ("Sat"), A. callosa ("Sat Gai La To"), A. griffitbiana Munro. ("Sat Gai La Nho"), and A. rovelli
Houz. de la Haie ("May Lang") (Vien Kinh Te Sinh Thai, 1994). Rare species listed by the WCMC are A. baviensis Bal. ("Sat Bavi") and A. vicinia King (Socialist Republic of Vietnam, 1992).

Dendrocalamus ("Luong”) species are distributed widely along the Truong Son mountain range (Vien Kinh Te Sinh Thai, 1994). Eleven species of Dendrocalamus have been described (Pham-hoang, 1993). The wellknown "Luong Thanh Hoa" from the southern Thanh Hoa province, Dendrocalamus membranaceus Munro ("Luong"), with canes that are very large in diameter $(10-12 \mathrm{~cm})$ and height $(20 \mathrm{~m})$, is being developed for use in housing and bridge construction. Luong is also grown in provinces of Hoa Binh, Son La, Nghe An, and Ha Tinh in northern Vietnam. Dendrocalamus patellaris Gamble ("Giang") is found in dense and mixed forests in the provinces of Nghe An, Thanh Hoa, Tuyen Quang, Vinh Phu, and Lao Cai. Giang produces a high-quality pulp and is used to produce string (Vien Kinh Te Sinh Thai, 1994). In the north, Giang is spread in the middle of roads to be flattened by passing automobiles for use for light construction, such as in fences or huts. Dendrocalamus flagellifer Munro ("Buong") produces the largest shoots, and $D$. giganteous Munro is the tallest bamboo (up to $35 \mathrm{~m}$ ). Other species listed by the Socialist Republic of Vietnam (1992) with no information on their status are $D$. poilanei Cam. and $D$. sinuata (Gamble) Holttum.

Lingnania ("Dung") species are grown in cool climates as border plants in villages of the Dao and Tay. They are highly rhizomatous and have long internodes $(40 \mathrm{~cm})$ and fibers. Important species are L. chungii Mc Clure ("Dung Nha") and L. cerossima McClure ("Mang Tan")(Vien Kinh Te Sinh Thai, 1994).

Oxytenanthera ("Le") are widespread in areas with dry seasons, such as the West Plateau in the provinces of Ninh Thuan, Kon Tum, and Daklak. They are small plants with a solid stem up to $8 \mathrm{~m}$ tall, are drought resistant, and useful as cover and border plants. They also have good edible shoots. An important species is $O$. albociliata Munro ("May Lay" and "May Sot") (Vien Kinh Te Sinh Thai, 1994). Several species for which we have no information on status include $O$. dinhensisee Cam. ("Le Nui Dinh") with tasty shoots and $O$. poilanei Cam. (Socialist Republic of Vietnam, 1992).

Phyllostachys species occupy $\approx 5 \%$ of the surface area of bamboo thickets, and are distributed at $700 \mathrm{~m}$ above sea level in Cao Bang, Bac Thai, Lang Son. Six species of Phyllostachys are found in Vietnam (Phamhoang, 1993), with the most economically important being $P$. pubescens Houz. de la Haie ("Truc Sao"), which is $\approx 20 \mathrm{~m}$ tall, and $P$. bambusoides Sieb. and Zucc. ("Truc Can Cau"), which is $\approx 10 \mathrm{~m}$ tall (Vien Kinh Te Sinh Thai, 1994).

Sinocalamus ("Mai") species grow in the forest where the ethnic minorities, Tay and Dao, are found. Mai are found in the provinces of Tuyen Quang, Bac Thai, Cao Bang, Lang Son, and Thanh Hoa. They are large bushes,
15-17 $\mathrm{m}$ tall and have large, thick-walled canes $(15-20 \mathrm{~cm})$ that are used for building construction, water pipes, and water containers. Their tasty, edible shoots are eaten fresh or dried. The most important species are $S$. giganteus (Munro) Keng f., S. latiflorus (Munro) McClure and S. farinosus Keng et Keng f. (Vien Kinh Te Sinh Thai, 1994).

\section{Coconuts ("Dua")}

Vietnam is in the native range of the important coconut species, Cocos nucifera L.. Its cultivation is widespread in the South, with its northern limit being the Thanh Hoa province. While coconut still covers a substantial acreage in Vietnam, its area has been greatly reduced from 400,000 ha in 1987 to 250,000 ha in 1995 because of poor prices and a switch to agronomic crops. About 50 diverse landraces were grown in Vietnam a few decades ago, but this number has been reduced to only 10 (Nguyen-van and Phan, 1995; Ton-that, 1974). Several more landraces, "Stripe," "Sweet" (Sweet husk), "Dua," "Sap," "Eo," and "Bi," face extinction in the Mekong delta (Nguyenvan and Phan, 1995). "Dua" is particularly notable for its pineapple fragrance and "Sap" for its high oil level. Little effort has been made to conserve this material.

\section{Sugarcane ("Mia")}

Vietnam is in the natural distributional range of at least three species of sugarcane (Roach, 1995). Wild Saccharum spontaneum L. is found countrywide, whereas native $S$. sinensis Robx. grows in the provinces of Lang Son and Tuyen Quang in northern Vietnam and the noble cane $S$. officinarum L. is widely cultivated (Nguyen-huy, 1996). Sugarcane is a particularly profitable cash crop in regions near cities. In Hoa Binh province sugarcane is used as a snack in the urban area of Hanoi, costing \$US 0.10-0.20 per cane as compared with \$US 0.20-0.30 per kg for rice (Le-tran Binh, pers. comm.). Sugarcane cultivation requires less labor than does rice cultivation, and growers in this region are assured of higher yields than with upland rice.

Many landraces of sugarcane are cultivated nationwide. One of the oldest sugarcane landraces may be "Mia Lau" (S. sinensis), which is cultivated in Quang Ngai, Bien Hoa, and Tan Uyen. It is mentioned in Vietnamese folk poems (Ton-that, 1970).

Within S. officinarum, the landrace "Mia Tien" is of particularly high quality, is grown in Thanh Hoa, and was once reserved for the sovereigns. In Phu Yen, Khanh Hoa, and Ninh Thuan, the landraces "Thanh Dieu" and "Mia Mung" are grown, with notably soft, sweet, juicy, and fragrant stems (Nguyen-huy, 1996). Many landraces of $S$. officinarum were introduced in the early 20 th century by the Indochina Agricultural Directorate; these include "Mia Son," "Thom," "Dieu" ("Black Cheribon" or "La haine purple"), "Mia Khoan Co" ("La haine striped"), "Mia Trang", "Mia Voi," ("Tanna"), "Mia Vang" or "Vang Tay" ("Yellow Caledonia") "Mia Mung," "Mia Tre," and "Mia Xanh" (Ton-that, 1970). 
Considerable work has been done in evaluating sugarcane lines in Vietnam. Ton-that (1970) observed that $S$. spontaneum and $S$. sinensis are not resistant to the black smut fungus, Ustilago scitamines Sydow. However, some strains of these two species are very resistant to root rot caused by Pythium sp. and some strains of $S$. spontaneum are very resistant to Collectotrichum falcatum (Physalospora tucumanensis Speg.). A total of 500 accessions were evaluated at the Center for Research in Sugarcane, with 250 from Vietnam. The Vietnamese and Chinese lines had among the largest stem diameters, while Taiwanese lines had the highest yield. Cuban lines had the highest sugar content and the strongest resistance to smut. Indian lines were most drought resistant, vigorous, had high stem numbers and high sugar content. Crosses have been made among these materials and the elite commercial lines of $S$. officinarum, and seven cultivars have been released in the last decade (Nguyen-huy, 1996).

\section{Tea ("Che")}

Pham-hoang (1991) described 29 Camellia sp. found countrywide. Within C. sinensis, the major species of commerce, he described four variants grown in Vietnam: 1) bohea (L.) Pierre; 2) viridis (L.) Pierre; 3) assamica (Mast.) Pierre; and 4) cantonensis (Lour.) Pierre. Although the major variant, $C$. sinensis var. sinensis, is not found in Vietnam, the Vietnamese variants bohea and viridis may be hybrids of var. sinensis and var. assamica, a Vietnamese native.

Tea plays an important role in Vietnamese life. It is prepared fresh or as a processed product scented with lotus or jasmine. In fact, the highly esteemed Sri Lankan tea, cultivar TRI 777, thought to be introduced to Vietnam in 1978, is actually a native of Vietnam. It was introduced to Sri Lanka in 1935 (Nguyendang, 1995). Further, the Chinese tea of Vietnamese origin, $C$. sinensis var. bohea, is currently being cultivated in Quang Tri, Central Vietnam, and is called "Tuoc Thiet" or "Tra Moc Cau" (Sparrow's tongue tea) (Lien Hiep Cac Hoi Khoa Hoc va Ky Thuat, 1996).

Tea plantations are numerous in the northern highlands, the midlands and the West Plateau of South Vietnam, with a total harvest area of 70,800 ha in 1996, up from 41,600 ha in 1985 . Tea exports brought \$US 15 million in revenue for Vietnam in 1995 (Food and Agriculture Organization, 1997); however, there is currently an oversupply of tea in the world market because of reduced tea consumption in developed countries (Ellis, 1995).

While $C$. sinensis is used solely as a stimulant, most of its numerous relatives are used as ornamentals. The strikingly elegant Hoa Hai Duong (Camellia sp.) is used to decorate northern Vietnamese homes during the New Year celebration. The fragant, bright-yellow flowers of Camellia sp. from the Cuc Phuong National Park have been used in ornamental breeding in France (Hoi Hoa Lan Cay Canh, 1995). Other native relatives, such as Schima wallichii (DC) Korth. sp. noronhae (B1.)
Bloemb., found in high mountains, contains saponin, which is used as fish poison (Phamhoang, 1991).

\section{FINAL THOUGHTS}

Vietnamis well-endowed with native germplasm of horticultural staple and industrial crops. It is also blessed with creative indigenous populations who still work the land for their survival. Vietnamese, after many years of war and isolation, have proved to themselves and the world that they are not only resilient but are quick to develop new innovations and adopt others. Their success in becoming a rice exporter again, using introduced cultivars from the International Rice Research Institute (IRRI), is an excellent example of how rapidly new technologies, related to food security, have been successfully applied given an agricultural policy that provides incentive to farmers.

Native germplasm of fruit, vegetable and spice crops are precious genetic resources with tremendous potential for further development in Vietnam, both for internal use and as export commodities to other parts of the world where these crops are important. The native germplasm described above holds the key to sustaining food production while conserving the environment. Many species can be used as nontraditional forms of agricultural income and can be grown in mountainous and deforested areas. Unfortunately, much of the native germplasm is being ignored or displaced by introduced, high-yielding varieties, new crops, and population pressure. Policies and technologies that are conducive to the conservation and breeding use of germplasm are essential.

\section{Literature Cited}

De Laroussilhe, F. 1980. Le manguier. Techniques agricoles et productions tropicales XXIX. G.P. Maisonneuve and Larose. Paris.

Denning G. L. and Vo-tong Xuan (eds.). 1995 Vietnam and IRRI: Partnership in rice research. Proc. of a conference 4-7 May 1994. Hanoi. IRRI-MAFI.

Do-dinh, Ca. 1996. Preliminary results of the observation, collection and conservation of citrus germplasm, p. 135-139. In: Plant genetics resources in Vietnam. Proc. Natl. Workshop Strengthening Plant Genet. Res. Vietnam. Hanoi, 28-30 Mar. 1995. Agr. Publ. House, Hanoi.

Do-dinh, Sam. 1994. Shifting cultivation in Vietnam: Its social, economic and environmental values relative to alternative land use. IIED Forestry and Land Use Series No. 3. Intl. Inst. Environ. Dev., London.

Do-tat, Loi. 1986. Nhung cay thuoc va vi thuoc Vietnam. Nha xuat ban khoa hoc va ky thuat Hanoi (Vietnamese medical plants and medicines). Science and Tech. Publ. House, Hanoi.

Ellis, R.T. 1995. Tea, Camellia sinensis (Camelliaceae), p. 22-27. In: J. Smartt and N.W. Simmonds (eds.). Evolution of crop plants. $2^{\text {nd }}$ ed. Longman Scientific \& Tech. Essex, England.

Food and Agriculture Organization. 1997.FAOSTATE agriculture data http://apps.fao.org/lim500/nphwrap.pl?Trade.CropsLivestockProducts\&Domain=SUA Government of the Socialist Republic of Vietnam and the Global Environmental Facility. 1994. Biodiversity action plan for Vietnam. Hanoi.

Hahn, S.K. 1995. Yams, Dioscorea spp. (Dioscoreaceae), p. 112-120. In: J. Smartt and N.W. Simmonds (eds.). Evolution of crop plants. $2^{\text {nd }}$ ed. Longman Scientific and Tech. Essex, England.

Hoi Hoa Lan Cay Canh. 1995. Tap San Hoa Canh, so 6: trang 15, thang 11. Thanh Pho Ho Chi Minh (Orchid and Hort. Soc. 1995. Garden and Landscape Magazine (6): 15 Nov. Ho Chi Minh City).

International Plant Genetic Resources Institute. 1994. Annual report. Intl. Plant Genet. Res. Inst., Rome.

Kostermans, J.G.H. and J. Bompard. 1993. The mangoes. Their botany, nomenclature, horticulture and utilization. Published for the Intl. Board for Plant Genet. Res. and the Linnean Soc. of London. Academic, New York.

Le-dinh, Danh. 1996. Fruit genetic resources at Phu Ho Fruit Crop Research Center, p. 132-134. In: Plant genetic resources in Vietnam. Proc. Natl. Workshop Strengthening Plant Genet. Res. Vietnam. Hanoi. 28-30 Mar. 1995. Agr. Publ. House, Hanoi.

Lien Hiep Cac Hoi Khoa Hoc va Ky Thuat. 1996. Khoa Hoc Pho Thong, trang 10, so Xuan Binh Ty 1996 Thanh Pho Ho Chi Minh (Fed. Sci. and Tech. Assoc. 1996. Popular Sci. Magazine, Lunar Binh Ty New Year 1996 issue, p. 10. Ho Chi Minh City).

Nguyen-dang, Khoi. 1995. Bao cao cua ban chu nhiem du an (Report of the project steering committee). Paper presented at the Natl. Workshop on Strengthening of Plant Genet. Res. Programme in Vietnam. 28-30 Mar. 1995. Hanoi.

Nguyen-huu, Nghia and Dan Ngo-the. 1996. Vietnam. Technology assessment and transfer for sustainable agriculture and rural development in the Asia-Pacific region. http://www.fao.org/ WAICENT/faoinfo/sustdev/RTdirect/ RTre0018.htm

Nguyen-huy, Uoc. 1996. On the collection, evaluation and utilization of sugar cane in Vietnam, $p$. 140-142. In: Plant genetics resources in Vietnam. Proc. Natl. Workshop Strengthening Plant Genet. Res. Vietnam. Hanoi. 28-30 Mar. 1995. Agr. Publ. House, Hanoi.

Nguyen-van, Minh and Lieu Phan. 1996. Potential development, genetic erosion and technologies for preserving oil plant genetic resource in Vietnam, p. 147-150. In: Plant genetic resources in Vietnam. Proc. Natl. Workshop Strengthening Plant Genet. Res. Vietnam. Hanoi. 28-30 Mar. 1995. Agr. Publ. House, Hanoi.

Pham-hoang, Ho. 1991. Cay Co Vietnam. Quyen I: Tap 1va 2. An illustrated flora of Vietnam. Mekong Printing. Santa Ana, Calif.

Pham-hoang, Ho. 1992. Cay Co Vietnam. Quyen II. Tap 1. An illustrated flora of Vietnam. Mekong Printing. Santa Ana, Calif.

Pham-hoang, Ho. 1993. Cay Co Vietnam. Quyen II: Tap 2, Quyen III: Tap 1 va 2. An illustrated flora of Vietnam. Mekong Printing. Santa Ana, Calif.

Pham-ngoc, Lieu and Pham-van Vui. 1995. Nhung giong cay an trai duoc ua chuong. So thang hai: trang 8. Phu Truong Nguoi Lam Vuon. Thanh Pho Can Tho. (Popular Fruits in Southern Vietnam. February issue, p. 8. Supplement pages to gardeners. Can Tho City.)

Plucknette, D.L., N.J.H. Smith, J.T. Williams, and N.M. Anishetty. 1987. Gene banks and the world's food. Princeton Univ. Press, Princeton, N.J.

Roach, B.T. 1995. Sugar canes. Saccharum (Gramineae), p. 160-165. In: J. Smartt and N.W.Simmonds (eds.). Evolution of crop plants. $2^{\text {nd }}$ ed. Longman Scientific and Tech. Essex, England. 
Sauer, J.D. 1993. Historical geography of crop plants: A selected roster. Rutaceace-Citrus family. CRC Press, Boca Raton, Fla. p. 138-144.

Scorza, R.W. 1988. Biochemistry, taxonomy and evolution of modern cultivated citrus, p. 277 289. In: R. Goren and K. Mendel (eds.). Proc. Sixth Intl. Citrus Congr., Rehovot, Israel.

Socialist Republic of Vietnam. 1988. Cong Hoa Xa Hoi Chu Nghia Vietnam. Dia Ly Tu Nhien Phan Dat Lien. Cuc Do Dac va Ban Do Nha Nuoc Nam (Natural geographic map. Dept. of Measurements and Maps).

Socialist Republic of Vietnam. 1992. Biodiversity. http://www.wcmc.org.uk/infoserv/countryp/ vietnam/

Swingle, W.T. and P.C. Reese. 1967. The botany of Citrus and its wild relatives, p. 190-430. In: W. Reuther, H.J. Webber, and L.D. Batchelor (eds.). The citrus industry. vol. 1. Div. of Agr. Sci., Univ. of Calif., Berkeley.

Ton-that, Trinh. 1970. Cai thien nganh trong mia ky nghe o Vietnam. Bo Canh Nong Xuat Ban. Saigon. (Improvement of sugarcane cultivation in Vietnam. Ministry of Agr. Saigon)

Ton-that, Trinh. 1973. Trong chuoi cai thien. Lua
Thieng Xuat Ban. Saigon. (Improvement of banana cultivation. Lua Thieng Publ. House. Saigon).

Ton-that, Trinh. 1974. Cai thien nganh trong dua tai Vietnam, trang 33-34. Bo Canh Nong Xuat Ban. Saigon. (Vietnam improvement of coconut cultivation, p. 33-34. Ministry of Agriculture. Saigon).

Ton-that, Trinh. 1995. Tim hieu ve cac loai cay an trai co trien vong xuat khau. Nha Xuat Ban Nong Nghiep. Vien Khoa Hoc Nong Nghiep Mien Nam. Thanh pho Ho Chi Minh. (Exploration of fruit crops with export potential. Agr. Publ. House. Agr. Inst. of South Vietnam. Ho Chi Minh City).

Tran-dinh, Dan. 1996a. National parks and nature reserves with their plant genetic resources in Vietnam, p. 85-86. In: Plant genetics resources in Vietnam. Proc. Natl. Workshop Strengthening Plant Genet. Res. Vietnam. Hanoi, 28-30 Mar. 1995. Agr. Publ. House, Hanoi.

Tran-dinh, Long. 1996b. The strategies for plant genetic resources conservation and utilization in Vietnam, p. 54-59. In: Plant genetics resources in Vietnam. Proc. Natl. Workshop Strengthen- ing Plant Genet. Res. Vietnam. Hanoi, 28-30 Mar. 1995. Agr. Publ. House, Hanoi.

Truong-van, Ho and Nguyen-ngoc Hue. 1996. Root and tuber crop genetic resources in Vietnam, $\mathrm{p}$. 126-129. In: Plant genetics resources in Vietnam. Proc. Natl. Workshop Strengthening Plant Genet. Res. Vietnam. Hanoi. 28-30 Mar. 1995. Agr. Publ. House, Hanoi.

Vien Kinh Te Sinh Thai. 1994. Tai nguyen rung Vietnam. p. 25-34. Chu bien. GS. TS. Nguyen Van Truong. Nha Xuat Ban Nong Nghiep. Hanoi. Econ. and Ecol. Inst. 1994. Vietnam forest natural resources, p. 25-34. Nguyen-van Truong (ed.). Agr. Publ. House. Hanoi.

Vien Quy Hoach va Thiet Ke Nong Nghiep. 1997. Mot so van de ve phan vung nong nghiep Vietnam (Issues related to agricultural zoning in Vietnam) Ministry of Agr. and Rural Dev. (MARD). Hanoi.

Vu-tuyen, Hoang. 1996. Conservation and diversification of plant genetic resources in Vietnam, $p$ 112-113. In: Plant genetic resources in Vietnam. Proc. Natl. Workshop Strengthening Plant Genet. Res. Vietnam. Hanoi. 28-30 Mar. 1995. Agr. Publ. House, Hanoi. 